\title{
PENGARUH BERBAGAI DOSIS PUPUK ORGANIK CAIR LIMBAH RUMAH TANGGA TERHADAP PERTUMBUHAN DAN HASIL TANAMAN PADI GOGO
}

\section{INFLUENCE OF VARIOUS LIQUID ORGANIC FERTILIZER OF HOUSEHOLD WASTE ON GROWTH AND RESULTS OF GOGO RICE PLANTS}

\author{
Izni $^{1}$, Aris Aksarah Pas ${ }^{1}$, Jumardin $^{1 *}$ \\ ${ }^{1}$ Program Studi Agroteknologi, Fakultas Pertanian Universitas Alkhairaat Palu \\ Jl. Diponegoro No. 39 Palu 94221, Indonesia
}

\begin{abstract}
ABSTRAK
Penelitian ini bertujuan untuk mempelajari respons pertumbuhan dan hasil tanaman padi gogo pada berbagai dosis pupuk organik cair limbah rumah tangga. Penelitian ini menggunakan Rancangan Acak Kelompok (RAK) satu faktor. Pengelompokan berdasarkan sinar matahari. Adapun perlakuan yang dicobakan yaitu berbagai dosis pupuk organik cair limbah rumah tangga $(\mathrm{POC})$ yakni, $\mathrm{POC}_{\mathrm{O}}=$ tanpa $\mathrm{POC}, \mathrm{POC}_{1}=200 \mathrm{ml} / \mathrm{tanaman}, \mathrm{POC}_{2}=250 \mathrm{ml} / \mathrm{tanaman}, \mathrm{POC}_{3}=300 \mathrm{ml} / \mathrm{tanaman}$. Hasil penelitian menunjukkan bahwa perlakuan berbagai dosis pupuk organik cair berpengaruh nyata terhadap pertumbuhan dan hasil tanaman padi gogodan perlakuan dosis $300 \mathrm{ml} /$ tanaman memberikan pengaruh yang lebih tinggi dibandingkan dengan perlakuan lainnya terhadap pertumbuhan dan hasil tanaman padi gogo.
\end{abstract}

Katakunci: POC, limbah rumah tangga, tanaman padi gogo

\section{ABSTRACT}

This study aims to study the growth response and yield of gogo rice at various doses of household waste organic fertilizer. This study uses a randomized block design (RAK) of one factor. Grouping based on sunlight. The treatment that was tried was various doses of household organic liquid fertilizer (POC), namely, $P O C O=$ without $P O C, P O C 1=200 \mathrm{ml} /$ plant,$P O C 2=250 \mathrm{ml} /$ plant, $P O C 3=300 \mathrm{ml} / \mathrm{plant}$. The results showed that the treatment of various doses of liquid organic fertilizer had a significant effect on the growth and yield of gogodan rice and the treatment dose of $300 \mathrm{ml} /$ plant had a higher effect compared to other treatments on the growth and yield of gogo rice plants.

Keywords: POC, household waste, gogo rice plants

\section{Pendahuluan}

Pembangunan perekonomian di Indonesia komoditi padi mempunyai peranan yang sangat penting, karena beras merupakan bahan makanan pokok bagi penduduk Indonesia. Pemerintah telah melakukan berbagai upaya untuk memenuhi kebutuhan beras Nasional seperti penerapan teknologi pada lahan sawah irigasi. Namun penerapan teknologi tersebut tidak seimbang dengan perluasan lahan. Setiap tahun terjadi konversi lahan pertanian ke non pertanian sehingga menyebakan luasan untuk pertanian

\footnotetext{
*) Penulis Korespondensi

E-mail: jumardin22@gmail.com

Telp: +62-85240935584
}

semakin menurun.

Peningkatan produksi beras dapat dilakukan dengan memanfaatkan lahan kering yang masih belum terkelola secara maksimal. Oleh karena itu, pengembangan tanaman padi gogo di lahan kering sangat mutlak untuk dilakukan. Namun pengelolaan lahan kering dihadapkan pada berbagai kendalah, yaitu lereng yang curam, bahaya erosi, longsor, ketersediaan air yang rendah, dan tingkat produktifitas lahan yang rendah. Basa $d k k$., (1991) mengemukakan paket teknologi untuk tanaman pangan pada lahan kering yang dianjurkan yaitu: penanaman varitas unggul, menggunakan pola tanaman pupuk buatan dan kapur, serta melakukan pengendalian hama, penyakit gulma secara terpadu. 


\section{Jurnal Agrotech 9 (1) 33-38}

Belakangan ini sistem pertanian berkelanjutan marak dikembangkan. Salah satu upaya yang diharapkan dapat memperbaiki atau meningkatkan produktivitas lahan adalah dengan pemberian bahan organik. Hal ini disebabkan karena bahan organik memiliki kemampuan untuk memperbaiki sifat fisik, kimia dan biologi tanah. Karena dengan peningkatan kandungan bahan organik dan cara konservasi bahan organik dapat dikatakan sebagai kunci keberhasilan usaha tani tanaman pangan (Musnamar, 2003)

Rendahnya produksi tanaman padi gogo dapat disebabkan oleh beberapa faktor yaitu teknik budidaya yang dilakukan petani yang belum intensif, faktor iklim dan tingkat kesuburan tanah yang rendah. Usaha yang dapat dilakukan untuk meningkatkan produksi tanaman sayuran tersebut salah satu diantaranya dengan pemberian pupuk. Pemupukan dilakukan dalam rangka untuk memenuhi kebutuhan unsur hara bagi tanaman, sehingga dapat memberikan hasil yang tinggi.

Pemberian pupuk kebanyakan dilakukan melalui tanah, namun cara tersebut mempunyai beberapa kelemahan, diantaranya adalah unsur hara menjadi tidak tersedia karena dapat mengalami pencucian, penguapan dan terfiksasi (diikat) oleh partikel tanah atau misel tanah (Sarief, 1989). Untuk mengatasi hal tersebut pemberian pupuk dapat dilakukan melalui tubuh tanaman atau dikenal dengan istilah pupuk daun. Kelebihan yang diperoleh dari pemberian pupuk melalui daun adalah pupuk daun umumnya mengandung unsur hara yang lengkap terdiri atas unsur makro dan unsur mikro, unsur hara lebih cepat larut sehingga cepat diserap tanaman.

Berbagai macam bahan organik dapat dimanfaatkan untuk pembuatan pupuk organik cair, yaitu limbah rumah tangga baik yang padat maupun yang cair. Untuk berhasilnya pemberian pupuk sangat ditentukan oleh macam pupuk, dosis dan cara pemupukan. Oleh karena itu, dilakukan penelitian tentang respons pertumbuhan dan hasil tanaman padi gogo pada berbagai dosis pupuk organik cair limbah rumah tangga.

\section{Metode Penelitian}

Penelitian ini menggunakan Rancangan Acak Kelompok (RAK) satu faktor. Pengelompokan berdasarkan sinar matahari. Adapun perlakuan yang dicobakan yaituberbagai dosis pupuk organik cair limbah rumah tangga (POC) sebagai berikut:
e-ISSN : 2621-7236

p-ISSN : 1858-134X

$\mathrm{POC}_{\mathrm{O}}=$ tanpa $\mathrm{POC}$

$\mathrm{POC}_{1}=200 \mathrm{ml} /$ tanaman

$\mathrm{POC}_{2}=250 \mathrm{ml} / \mathrm{tanaman}$

$\mathrm{POC}_{3}=300 \mathrm{ml} /$ tanaman

Setiap perlakuan diulang sebanyak 3 kali sehingga terdapat 12 unit percobaan.Setiap unit terdapat 3 polybag, sehingga secara keseluruhan terdapat 36 polybag. Untuk melihat pengaruh perlakuan yang dicobakan dilakukan uji keragaman dan bila hasil uji keragaman menunjukkan pengaruh nyata dilanjutkan dengan uji Beda Nyata Terkecil (BNT) $\alpha=0,05$ (Gomez \& Gomez, 2007).

\section{Pelaksanaan}

Persiapan media tumbuh

Pembuatan media diawali dengan persiapan media tumbuh berupa polybag berukuran $40 \mathrm{~cm} \times 30 \mathrm{~cm}$ yang diisi sesuai dengan tanah yang sudah dicampurkan dengan bokashi pupuk kandang sapi dosis 10 ton/ha sebagai pupuk dasar

\section{Penanaman}

Penanaman dilakukan cara tugal. Setelah lubang bekas tugal terbentuk kemudian 3 benih dimasukkan ke dalam setiap lubang tanam dan selanjutnya ditutup kembali dengan tanah.

Pemeliharaan

\section{Penyulaman}

Penyulaman padi gogo dilakukan pada umur 3 minggu setelah tanam.

2. Penyiangan

Dilakukan secara fisik dengan cara mencabut rumput yang terdapat di dalam polibag, sedangkan sube dan sabit gunakan pada tempat media tanam. Penyiangan dilakukan waktu tanaman berumur 3-4 minggu. Pembumbunan dilakukan bersamaan dengan penyiangan pertama dan 1-2 minggu sebelum muncul malai.

Pembuatan pupuk organik cair limbah rumah tangga

Adapun bahan yang digunakan sebagai berikut :

1. Limbah rumah tangga (kol, kangkung, bayam, papaya, sawi) masing-masimg $3 \mathrm{~kg}$

2. Gula merah sebanyak 1 ons

3. Air cucian beras sebanyak 5 liter

Adapun cara pembuatan sebagai berikut :

1. Semua limbah rumah tangga dilakukan pengerusan

2. Setelah pengerusan, larutkan gula merah dengan 5 liter air cucian beras 


\section{Jurnal agrotech 9 (1) 33-38}

3. Masukkan semua bahan ke dalam wadah yang tertutup rapat kemudian didiamkan selam 14 hari

4. Setelah 14 hari mol tersebut dapat diaplikasikan.

5. Untuk aplikasi 1 liter mol ditambahkan dengan 10 liter air.

Aplikasi Perlakuan

Aplikasi pupuk organik cair limbah rumah tangga diberikan dua kali yakni saat tanam dan $30 \mathrm{HST}$.

\section{Pengamatan}

1. Tinggi tanaman diukur dari permukaan tanah sampai daun tertinggi yang diukur setiap minggu mulai dari 4 MST dan 8 MST

2. Jumlah anakan dihitung mulai dari 4 MST dan 8 MST

3. Umur berbunga $50 \%$ (hari) yakni waktu yang diperlukan tanaman sejak tanaman hinggga mencapai $50 \%$ tanaman mengeluarkan malai
e-ISSN : 2621-7236

p-ISSN : 1858-134X

4. Jumlah anakan produktif yaitu anakan yang menghasilkan malai dalam satu rumpun

5. Panjang malai diukur dari pangkal malai hingga ujung malai dengan mengukur malai setiap rumpun tanaman

6. Jumlah bulir per malai. Dihitung pada saat panen

7. Berat basah tanaman (g). Ditimbang pada saat panen

8. Berat kering tanaman (g). Ditimbang saat berat sudah konstan

\section{Hasil dan Pembahasan}

Tinggi tanaman $(\mathrm{cm})$

Hasil analisis ragam menunjukkan perlakuan berbagai dosis pupuk organik cair limbah rumah tangga berpengaruh nyata terhadap tinggi tanaman padi gogo.

Tabel 1. Rata-rata tinggi tanaman $(\mathrm{cm})$ padi gogo pada perlakuan berbagai dosis pupuk organik cair limbah rumah tangga

\begin{tabular}{lcc}
\hline \multicolumn{1}{c}{ Berbagai Dosis } & \multicolumn{2}{c}{ Umur } \\
\cline { 2 - 3 } & $\mathbf{4}$ MST & $\mathbf{8 ~ M S T}$ \\
\hline POC $_{\mathrm{O}}=$ tanpa pupuk organik cair & $48.53 \mathrm{a}$ & $81.33 \mathrm{~b}$ \\
$\mathrm{POC}_{1}=200 \mathrm{ml} /$ tanaman & $47.20 \mathrm{a}$ & $82.33 \mathrm{a}$ \\
$\mathrm{POC}_{2}=250 \mathrm{ml} /$ tanaman & $45.57 \mathrm{~b}$ & $81.80 \mathrm{~b}$ \\
$\mathrm{POC}_{3}=300 \mathrm{ml} /$ tanaman & $49.33 \mathrm{a}$ & $84.53 \mathrm{a}$ \\
\hline BNT $\boldsymbol{\alpha}=\mathbf{0 , 0 5}$ & $\mathbf{3 , 5 4}$ & $\mathbf{2 , 7 8}$ \\
\hline
\end{tabular}

Keterangan : Angka-angka yang diikuti oleh huruf sama pada kolom sama berarti berbeda tidak nyata pada taraf uji BNT $\dot{\alpha}=0,05$

Hasil uji BNT $\alpha=0,05$ menunjukkan bahwa perlakuan dosis pupuk organik cair limbah rumah tangga $300 \mathrm{ml} /$ tanaman $\left(\mathrm{POC}_{3}\right)$ memberikan pengaruh yang lebih tinggi terhadap tinggi tanaman padi gogo meskipun berbeda tidak nyata dengan perlakuan lainnya kecuali perlakuan $250 \mathrm{ml} / \mathrm{tanaman}\left(\mathrm{POC}_{2}\right)$ pada umur 4 MST. Pada umur 8 MST, perlakuan 300 $\mathrm{ml} /$ tanaman $\left(\mathrm{POC}_{3}\right)$ memberikan pengaruh yang lebih tinggi terhadap tinggi tanaman dibandingkan dengan perlakuan lainnya

Tabel 2. Rata-rata jumlah anakan (batang) tanaman padi gogo pada perlakuan dosis pupuk organik cair limbah rumah tangga

\begin{tabular}{lcc}
\multicolumn{2}{c}{ Bimbah rumah tangga } & \multicolumn{2}{c}{ Umur } \\
\cline { 2 - 3 } Berbagai Dosis & 4 MST & $\mathbf{8 ~ M S T}$ \\
\hline $\mathrm{POC}_{\mathrm{O}}=$ tanpa pupuk organik cair & $3.00 \mathrm{~b}$ & $9.00 \mathrm{~b}$ \\
$\mathrm{POC}_{1}=200 \mathrm{ml} /$ tanaman & $3.00 \mathrm{~b}$ & $10.33 \mathrm{~b}$ \\
$\mathrm{POC}_{2}=250 \mathrm{ml} /$ tanaman & $3.33 \mathrm{~b}$ & $10.00 \mathrm{~b}$ \\
$\mathrm{POC}_{3}=300 \mathrm{ml} /$ tanaman & $4.00 \mathrm{a}$ & $10.67 \mathrm{a}$ \\
\hline BNT $\boldsymbol{\alpha}=\mathbf{0 , 0 5}$ & $\mathbf{0 , 4 4}$ & $\mathbf{0 , 3 0}$ \\
\hline
\end{tabular}

Keterangan : Angka-angka yang diikuti oleh huruf sama pada kolom sama berarti berbeda tidak nyata pada taraf uji BNT $\dot{\alpha}=0,05$ meskipun berbeda tidak nyata dengan perlakuan $200 \mathrm{ml} / \operatorname{tanaman}\left(\mathrm{POC}_{1}\right)$ namun berbeda nyata dengan perlakuan tanpa pupuk organik cair dan $250 \mathrm{ml} /$ tanaman $\left(\mathrm{POC}_{2}\right)$.

Jumlah anakan (batang)

Hasil analisis ragam menunjukkan perlakuan berbagai dosis pupuk organik cair limbah rumah tangga berpengaruh nyata terhadap jumlah anakan padi gogo 


\section{Jurnal Agrotech 9 (1) 33-38}

Hasil uji BNT $\alpha=0,05$ menunjukkan bahwa perlakuan dosis pupuk organik cair limbah rumah tangga $300 \mathrm{ml} / \mathrm{tanaman}\left(\mathrm{POC}_{3}\right)$ memberikan pengaruh yang lebih banyak terhadap jumlah anakan tanaman padi gogo pada seluruh umur tanaman dan berbeda nyata dengan perlakuan lainnya.

Tabel 3. Rata-rata umur berbunga $50 \%$ (hari) tanaman padi gogo pada perlakuan berbagai dosis pupuk organik cair limbah rumah tangga

\begin{tabular}{lc}
\hline \multicolumn{1}{c}{ Berbagai Dosis } & Umur Berbunga 50\% (hari) \\
\hline POCO $=$ tanpa pupuk organik cair & $60.33 \mathrm{~b}$ \\
POC $1=200 \mathrm{ml} / \operatorname{tanaman}$ & $59.67 \mathrm{~b}$ \\
POC $2=250 \mathrm{ml} / \operatorname{tanaman}$ & $58.33 \mathrm{a}$ \\
POC $3=300 \mathrm{ml} / \operatorname{tanaman}$ & $57.67 \mathrm{a}$ \\
\hline BNT $\boldsymbol{\alpha}=\mathbf{0 , 0 5}$ & $\mathbf{1 , 7 9}$
\end{tabular}

Keterangan : Angka-angka yang diikuti oleh huruf sama pada kolom sama berarti berbeda tidak nyata pada taraf uji BNT $\alpha=0,05$

Hasil uji BNT $\alpha=0,05$ menunjukkan bahwa perlakuan dosis pupuk organik cair limbah rumah tangga $300 \mathrm{ml} / \mathrm{tanaman}\left(\mathrm{POC}_{3}\right)$ memberikan umur berbunga yang lebih cepat dibandingkan dengan perlakuan lainnya, meskipun berbeda tidak nyata dengan 250 $\mathrm{ml} /$ tanaman $\left(\mathrm{POC}_{2}\right)$ namun berbeda nyata dengan perlakuan tanpa pupuk organik cair limbah rumah tangga $\left(\mathrm{POC}_{0}\right)$ dan $200 \mathrm{ml} / \mathrm{tanaman}$ $\left(\mathrm{POC}_{1}\right)$

Jumlah anakan produktif (batang)

Hasil analisis ragam menunjukkan perlakuan berbagai dosis pupuk organik cair limbah rumah tangga berpengaruh nyata terhadap jumlah anakan produktif tanaman padi gogo

Tabel 4. Rata-rata jumlah anakan produktif (batang) tanaman padi gogo pada perlakuan berbagai dosis pupuk organik cair limbah rumah tangga

\begin{tabular}{lc}
\hline \multicolumn{1}{c}{ Berbagai Dosis } & Anakan Produktif (batang) \\
\hline $\mathrm{POC}_{\mathrm{O}}=$ tanpa pupuk organik cair & $6.33 \mathrm{~b}$ \\
$\mathrm{POC}_{1}=200 \mathrm{ml} /$ tanaman & $7.67 \mathrm{~b}$ \\
$\mathrm{POC}_{2}=250 \mathrm{ml} /$ tanaman & $8.67 \mathrm{a}$ \\
$\mathrm{POC}_{3}=300 \mathrm{ml} /$ tanaman & $9.33 \mathrm{a}$ \\
\hline BNT $\boldsymbol{\alpha}=\mathbf{0 , 0 5}$ & $\mathbf{0 , 9 0}$ \\
\hline
\end{tabular}

Keterangan : Angka-angka yang diikuti oleh huruf sama pada kolom sama berarti berbeda tidak nyata pada taraf uji BNT $\alpha=0,05$

Hasil uji BNT $\alpha=0,05$ menunjukkan bahwa perlakuan dosis pupuk organik cair limbah rumah tangga tangga $300 \mathrm{ml} /$ tanaman $\left(\mathrm{POC}_{3}\right)$ memberikan jumlah anakan produktif yang lebih banyak dibandingkan dengan perlakuan lainnya, meskipun berbeda tidak nyata dengan 250 $\mathrm{ml} /$ tanaman $\left(\mathrm{POC}_{2}\right)$ namun berbeda nyata dengan perlakuan tanpa pupuk organik cair limbah

Tabel 5. Rata-rata panjang malai $(\mathrm{cm})$ tanaman padi gogo pada perlakuan berbagai dosis pupuk organik cair limbah rumah tangga

\begin{tabular}{lc}
\hline \multicolumn{1}{c}{ Berbagai Dosis } & Panjang Malai $(\mathbf{c m})$ \\
\hline $\mathrm{POC}_{\mathrm{O}}=$ tanpa pupuk organik cair & $23.33 \mathrm{~b}$ \\
$\mathrm{POC}_{1}=200 \mathrm{ml} /$ tanaman & $25.11 \mathrm{~b}$ \\
$\mathrm{POC}_{2}=250 \mathrm{ml} /$ tanaman & $26.04 \mathrm{a}$ \\
$\mathrm{POC}_{3}=300 \mathrm{ml} / \mathrm{tanaman}$ & $26.18 \mathrm{a}$ \\
\hline BNT $\boldsymbol{\alpha}=\mathbf{0 , 0 5}$ & $\mathbf{2 , 7 6}$ \\
\hline
\end{tabular}

Keterangan : Angka-angka yang diikuti oleh huruf sama pada kolom sama berarti berbeda tidak nyata pada taraf uji BNT $\alpha=0,05$

Hasil uji BNT $\alpha=0,05$ menunjukkan bahwa perlakuan dosis pupuk organik cair limbah rumah tangga $\left(\mathrm{POC}_{0}\right)$ dan $200 \mathrm{ml} / \mathrm{tanaman}$ $\left(\mathrm{POC}_{1}\right)$

Panjang malai $(\mathrm{cm})$

Hasil analisis ragam menunjukkan perlakuan berbagai dosis pupuk organik cair limbah rumah tangga berpengaruh nyata terhadap panjang malai tanaman padi gogo saat panen.

rumah tangga $300 \mathrm{ml} / \mathrm{tanaman} \quad\left(\mathrm{POC}_{3}\right)$ memberikan panjang malai yang lebih panjang 
dibandingkan dengan perlakuan lainnya, meskipun berbeda tidak nyata dengan 250 $\mathrm{ml} /$ tanaman $\left(\mathrm{POC}_{2}\right)$ namun berbeda nyata dengan perlakuan tanpa pupuk organik cair limbah rumah tangga $\left(\mathrm{POC}_{0}\right)$ dan $200 \mathrm{ml} / \mathrm{tanaman}$ $\left(\mathrm{POC}_{1}\right)$
Jumlah bulir per malai

Hasil analisis ragam menunjukkan perlakuan berbagai dosis pupuk organik cair limbah rumah tangga berpengaruh nyata terhadap jumlah bulir per malai tanaman padi gogo saat panen.

Tabel 6. Rata-rata jumlah bulir per malai tanaman padi gogo pada perlakuan berbagai dosis pupuk organik cair limbah rumah tangga

\begin{tabular}{lc}
\hline \multicolumn{1}{c}{ Berbagai Dosis } & Jumlah Bulir (butir) \\
\hline $\mathrm{POC}_{\mathrm{O}}=$ tanpa pupuk organik cair & $199.78 \mathrm{~b}$ \\
$\mathrm{POC}_{1}=200 \mathrm{ml} /$ tanaman & $209.33 \mathrm{~b}$ \\
$\mathrm{POC}_{2}=250 \mathrm{ml} / \mathrm{tanaman}$ & $232.44 \mathrm{a}$ \\
$\mathrm{POC}_{3}=300 \mathrm{ml} / \mathrm{tanaman}$ & $224.78 \mathrm{a}$ \\
\hline BNT $\boldsymbol{\alpha}=\mathbf{0 , 0 5}$ & $\mathbf{1 0 , 3 4}$
\end{tabular}

Keterangan : Angka-angka yang diikuti oleh huruf sama pada kolom sama berarti berbeda tidak nyata pada taraf uji BNT $\alpha=0,05$

Hasil uji BNT $\alpha=0,05$ menunjukkan bahwa perlakuan dosis pupuk organik cair limbah rumah tangga $250 \quad \mathrm{ml} / \mathrm{tanaman}$ $\left(\mathrm{POC}_{2}\right)$ memberikan jumlah bulir yang lebih banyak dibandingkan dengan perlakuan lainnya, meskipun berbeda tidak nyata dengan 300 $\mathrm{ml} /$ tanaman $\left(\mathrm{POC}_{3}\right)$ namun berbeda nyata dengan perlakuan tanpa pupuk organik cair limbah

rumah tangga $\left(\mathrm{POC}_{0}\right)$ dan $200 \mathrm{ml} / \mathrm{tanaman}$ $\left(\mathrm{POC}_{1}\right)$

Berat basah tanaman $(\mathrm{g})$

Hasil analisis ragam menunjukkan perlakuan berbagai dosis pupuk organik cair limbah rumah tangga berpengaruh nyata terhadap berat basah tanaman padi gogo saat panen.

Tabel 7. Rata-rata berat basah (g) tanaman padi gogo pada perlakuan berbagai dosis pupuk organik cair limbah rumah tangga

\begin{tabular}{lc}
\hline \multicolumn{1}{c}{ Berbagai Dosis } & Berat Basah $(\mathbf{g})$ \\
\hline POC $_{\mathrm{O}}=$ tanpa pupuk organik cair & $176.00 \mathrm{~b}$ \\
$\mathrm{POC}_{1}=200 \mathrm{ml} /$ tanaman & $159.67 \mathrm{~b}$ \\
$\mathrm{POC}_{2}=250 \mathrm{ml} /$ tanaman & $187.67 \mathrm{a}$ \\
$\mathrm{POC}_{3}=300 \mathrm{ml} /$ tanaman & $201.00 \mathrm{a}$ \\
\hline BNT $\boldsymbol{\alpha}=\mathbf{0 , 0 5}$ & $\mathbf{2 0 , 0 9}$ \\
\hline
\end{tabular}

Keterangan : Angka-angka yang diikuti oleh huruf sama pada kolom sama berarti berbeda tidak nyata pada taraf uji BNT $\dot{\alpha}=0,05$

Hasil uji BNT $\alpha=0,05$ menunjukkan bahwa perlakuan dosis pupuk organik cair limbah rumah tangga $300 \mathrm{ml} /$ tanaman $\left(\mathrm{POC}_{3}\right)$ memberikan berat basah yang lebih berat dibandingkan dengan perlakuan lainnya, meskipun berbeda tidak nyata dengan 250 $\mathrm{ml} /$ tanaman $\left(\mathrm{POC}_{2}\right)$ namun berbeda nyata dengan perlakuan tanpa pupuk organik cair limbah

Tabel 8. Rata-rata berat kering (g) tanaman padi gogo pada perlakuan berbagai dosis pupuk organik cair limbah rumah tangga

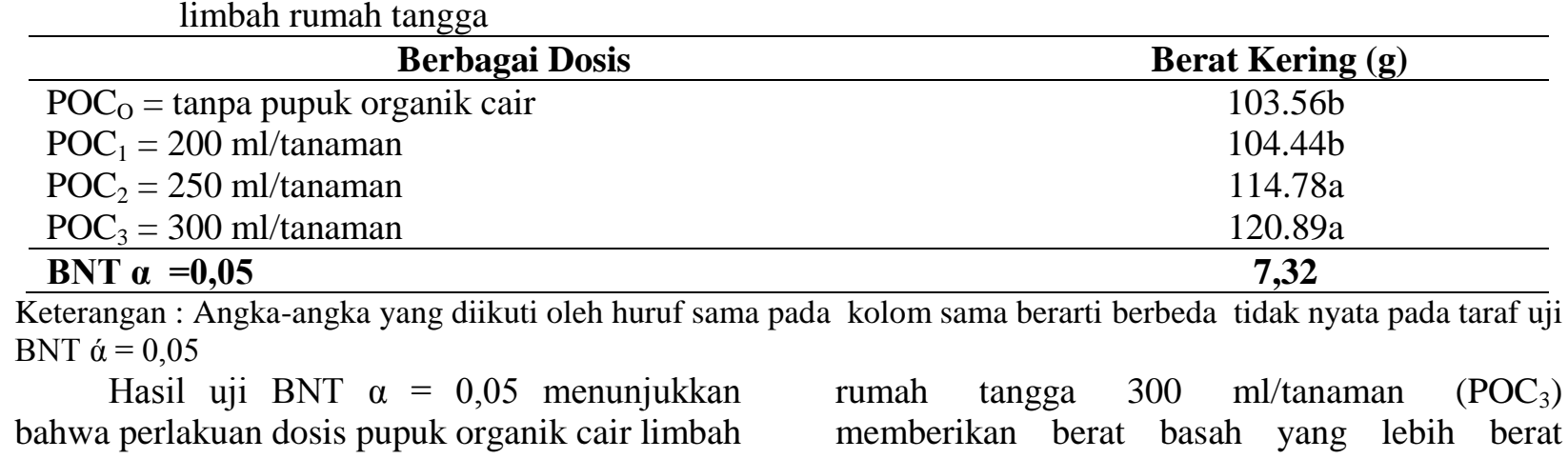

Keterangan : Angka-angka yang diikuti oleh huruf sama pada kolom sama berarti berbeda tidak nyata pada taraf uji BNT $\dot{\alpha}=0,05$

Hasil uji BNT $\alpha=0,05$ menunjukkan bahwa perlakuan dosis pupuk organik cair limbah $\left(\mathrm{POC}_{1}\right)$

\section{Berat kering tanaman $(\mathrm{g})$}

Hasil analisis ragam menunjukkan perlakuan berbagai dosis pupuk organik cair limbah rumah tangga berpengaruh nyata terhadap berat kering tanaman padi gogo saat panen. rumah tangga $\left(\mathrm{POC}_{0}\right)$ dan $200 \mathrm{ml} /$ tanaman 


\section{Jurnal Agrotech 9 (1) 33-38}

dibandingkan dengan perlakuan lainnya, meskipun berbeda tidak nyata dengan 250 $\mathrm{ml} /$ tanaman $\left(\mathrm{POC}_{2}\right)$ namun berbeda nyata dengan perlakuan tanpa pupuk organik cair limbah rumah tangga $\left(\mathrm{POC}_{0}\right)$ dan $200 \mathrm{ml} / \mathrm{tanaman}$ $\left(\mathrm{POC}_{1}\right)$

\section{Pembahasan}

Hasil penelitian menunjukkan bahwa perlakuan berbagai dosis pupuk organik cair limbah rumah tangga memberikan pengaruh terhadap pertumbuhan dan hasil tanaman padi gogo yakni pada parameter tinggi tanaman, jumlah anakan, umur berbunga, jumlah anakan produktif dan panjang malai. Hal ini menunjukkan bahwa, Hal ini diduga kandungan unsur hara yang terdapat didalam pupuk organik cair buatan sendiri mampu menyediakan unsur hara yang dibutuhkan tanaman padi gogo dalam menunjang pertumbuhan dan meningkatkan produksi.

Berdasarkan hasil analisis yang dilakukan di Laboratorium Ilmu Tanah Fakultas Pertanian Universitas Tadulako (2017), pupuk organik cair buatan sendiri mengandung $\mathrm{N} 0,45 \%, \mathrm{P} 0,02 \%$ dan K 0,06\% dan C-Organik 1, $22 \%$. Diduga dengan kandungan Nitrogen $(\mathrm{N})$ cenderung dapat memacu pertumbuhan dan perkembangan tanaman, karena pada saat pertumbuhan vegetatif (akar,batang dan daun) unsur nitrogen paling banyak diperlukan.

Hasil penelitian menunjukkan bahwa penggunaan dosis $300 \mathrm{ml} /$ tanaman merupakan perlakuan yang memberikan pengaruh yang lebih baik dibandingkan dengan perlakuan lainnya. Hal ini menunjukkan bahwa pemberian dosis dengan jumlah yang tepat mampu menyediakan unsur hara terhadap tanaman padi gogo.

Hal ini sejalan dengan dengan pendapat Agustina (1990), bahwa ketersediaan unsur hara dalam jumlah yang cukup dan seimbang merupakan faktor utama yang sangat menentukan tingkat keberhasilan pertumbuhan dan produksi tanaman. Ditambahkan oleh Lakitan (2007), jika kebutuhan hara tanaman terpenuhi, maka tanaman akan lebih optimal dalam memanfaatkan sinar matahari dan air dalam menjalankan proses metabolisme dalam jaringan yaitu dalam meningkatkan proses fotosintesis sehingga meningkatkan fotosintat yang bermanfaat membantu pembelahan dan pembesaran sel sehingga tanaman dapat tumbuh dan menghasilkan produksi yang maksimal yang ditunjukkan dengan perkembangan organ-organ tanaman yang baik.
e-ISSN : 2621-7236

p-ISSN : 1858-134X

\section{Kesimpulan dan Saran}

\section{Kesimpulan}

Setelah melaksanakan penelitian ini maka dapat disimpulkan bahwa:

1. Perlakuan berbagai dosis pupuk organik cair limbah rumah tangga berpengaruh nyata terhadap pertumbuhan dan hasil tanaman padi gogo

2. Perlakuan dosis $300 \mathrm{ml} / \mathrm{tanaman}$ memberikan pengaruh yang lebih tinggi dibandingkan dengan perlakuan lainnya terhadap pertumbuhan dan hasil tanaman padi gogo.

\section{Saran}

Perlu dilakukan penelitian lebih lanjut dengan dosis $300 \mathrm{ml} /$ tanaman pada percobaan yang dilakukan di lahan.

\section{Daftar Pustaka}

Agustina, L. 1990. Nutrisi Tanaman. Rineka Cipta. Jakarta.

Basa I. D. Pasaribu. Dan E. Suhartatik. 1991. Peran Pupuk Organik Terhadap Paket Teknologi Pola Tanam Pangan Lahan Kering. Makalah dalam Seminar Hasil Penelitian Tanaman Pangan Balittan, Bogor.

Gomez A. A,. \& K. A. Gomez, 2007. Prosedur Statistik untuk Penelitian Pertanian. Diterjemahkan oleh E. Syamsuddin dan Justika S. B. U-1 Press Jakarta

Lakitan, B. 2007. Dasar-dasar Fisiologi Tumbuhan. Raja Grafindo, Jakarta.

Musnamar, E.I. 2003. Pembuatan dan Aplikasi Pupuk Organik Padat. Penebar Swadaya, Jakarta.

Sarief, E. S., 1989. Fisika-Kimia Tanah Pertanian. Pustaka Buana, Bandung. 220 Hal

Universitas Tadulako, 2017. Analisis Kandungan Pupuk Organik Cair Limbah Rumah Tangga. Laboratorium Ilmu Tanah, Universitas Tadulako. Palu, Sulawesi Tengah. 